\title{
Unburnt building materials in the trend of sustainable development - Situation and solutions in the Mekong Delta, Vietnam
}

\author{
Truong Thi Hoang Oanh ${ }^{1 *}$, Duong Ngoc Thanh ${ }^{2}$, Truong Thi Be Hai ${ }^{3}$ \\ ${ }^{1}$ University of Economics Ho Chi Minh City - Campus in Vinh Long, Vietnam \\ ${ }^{2}$ Can Tho University, Vietnam \\ ${ }^{3}$ Tra Vinh University, Vietnam \\ *Corresponding author: oanhtth@ueh.edu.vn
}

\begin{abstract}
ARTICLE INFO
ABSTRACT

DOI: $10.46223 / \mathrm{HCMCOUJS}$. econ.en.12.1.1984.2022

Received: July $05^{\text {th }}, 2021$

Revised: November $06^{\text {th }}, 2021$

Accepted: December 04 ${ }^{\text {th }}, 2021$

Keywords:

consumption; Mekong Delta; production; sustainable development; unburnt building materials

The purpose of this article is to assess the current situation of production and consumption of Unburnt Building Materials (UBMs) in the Mekong Delta, thereby proposing solutions to promote the consumption of UBMs in the Mekong Delta in the coming time. Research results from the survey of producers and customers organized as well as discussions with local officials show that the whole Mekong Delta has more than 120 producers consuming through 02 main channels. Sales channels that direct customers are construction contractors - organizational customers (accounting for 90\%) and through construction material trading companies (about 10\%). In general, both the production and consumption of UBMs in the Mekong Delta face difficulties. Limited production capacity, limited capacity of UBMs, and low consumer confidence in UBM products are typical difficulties. Planning for the development of UBMs, organizing production to improve the innovation capacity of manufacturers and construction contractors, strengthening the link between manufacturers and UBMs consuming partners, promoting product branding products, enhancing sales promotion innovation activities, etc. are the main solutions to promote this industry to develop more in the Mekong Delta in the coming time.
\end{abstract}

\section{Introduction}

Over the years, sustainable production and consumption have been the use of goods and services that meet basic needs and provide a better quality of life while reducing the use of natural resources. However, minimizing hazardous materials and reducing emissions of pollutants over the entire product lifecycle with the goal of not endangering future generations (D. T. Nguyen, 2013). In recent decades, Unburnt Building Materials (UBM) have become a prominent topic, recognized as an urgent need and inevitable trend in the development process of Vietnam's building materials industry. The concept of unburnt building materials is defined by the Ministry of Construction (2017). UBM is a type of materials and components with different shapes and sizes, made from many different materials including binders, aggregates, additives, and water, according to different technologies, without going through fired stages and used in construction 
such as building retaining walls, partition walls of buildings or similar structures. UBM has outstanding advantages including (1) can be manufactured in any required compressive strength from low to high; (2) construction materials of large size, precision, no warping, easy to create large voids in the product forming process; (3) simple production technology, easy capacity expansion, available production materials, taking advantage of industrial wastes to help reduce environmental pollution; (4) reducing labour costs for plastering, reducing the volume of plastering mortar due to the large size of bricks, smooth flat surface and a number of other advantages (Ministry of Construction, 2019). This helps to overcome the limitations of traditional fired bricks. Firstly, the production of traditional fired bricks consumes a non-renewable resource of clay: If cultivated clay is used to produce baked clay bricks, the arable land will be lost more and more, which may cause affecting the food security of our country (Ministry of Construction, 2019). Second, the production of traditional fired bricks consumes a lot of energy and pollutes the environment. The production of clay bricks must go through the firing stage, mainly using fossil fuels such as coal (from rice husks, bran, honeycomb coal, etc.) - This is also a non-renewable fuel (Ministry of Construction, 2019). If the output of baked clay bricks increases, it will lead to a large amount of coal used; during the production process, a large amount of toxic $\mathrm{CO}_{2}$ and $\mathrm{SO}_{2}$ emissions will be released into the atmosphere (Ministry of Construction, 2019). Consequences affect the living environment, human health, reduce the yield of rice and surrounding crops (Ministry of Construction, 2019). Third, because baked clay bricks are small in size, it will take more labour to build walls and more mortar to use for plastering than unburnt bricks (Ministry of Construction, 2019). Because of the above problems, many countries around the world, especially developed countries, have used the solution by gradually reducing the production and use of baked clay bricks from $30 \%$ to $50 \%$ and increasing production and use of unburnt building materials at the rate of 50 to $70 \%$ of the total output of building materials (Ministry of Construction, 2019).

The national conference summarizing 10 years of implementation of the UBM Development Program held in Hanoi (Vietnam) in December 2020 emphasized UBM development as a development direction suitable for national sustainable development programs, and other industries have contributed to helping Vietnam become a highly appreciated country for the United Nations Millennium Program, for a Sustainable World, to respond to climate change. To achieve this goal, the Government of Vietnam has also issued the "Strategy for development of building materials in Vietnam for the period of 2021 - 2030" (Prime Minister, 2020). In the UBM development Program in Vietnam to 2030 is one of the important points to be emphasized. The Mekong Delta is of particular interest because it is the place that is both affected by the impact of climate change the most in the country and is home to the largest number of fired clay brick pottery villages in Vietnam. Since 2000, the Government has made many decisions to implement the roadmap to terminate the operation of manual brick kilns producing baked clay bricks, limit the production and use of new technology baked clay bricks and require increased use of UBM (K. M. Nguyen, 2000; Ministry of Construction, 2012; Prime Minister, 2010; Prime Minister, 2011). The Mekong Delta also focuses on key objectives of establishing and developing the industry of UBMs in accordance with regional conditions. In recent years, production output throughout the Mekong Delta has always fluctuated. UBMs producers face many difficulties and obstacles due to the fact that most enterprises are young, with low-level technological lines (Ministry of Construction, 2020) and fluctuations in product consumption. However, Mekong Delta producers also have certain advantages in participating in the production of UBMs. To better understand the above issues, the topic was formed to reflect the actual situation of production and consumption of UBMs. On that basis, this article proposes some solutions to improve the production and consumption of UBMs for enterprises in the Mekong Delta. 


\section{Research methods}

The data presented in this study are compiled from reports, statistics, and survey results of 236 enterprises, including 78 manufacturers, 158 construction firms, and trading firms (with UBMs) in 13 provinces and cities in the Mekong Delta. To carry out the survey, the author sent the introduction letter of her working Unit to the Departments of Construction in 13 provinces in the Mekong Delta. After receiving feedback, the author briefly discussed the interview content with the direct manager of the Construction Management Department of the Department of Construction in these provinces by phone to agree on the content and create the appointments which working with survey subjects - Board of Directors in charge of production and business, Head of the sales department of enterprises. After obtaining the consent of the production facilities operating at the study, the survey was conducted. In addition, the study also collected information from 10 people from organizations and individuals involved in the management of the building materials industry, construction designers, construction supervisors using UBMs to clearly confirm more than accuracy and objectivity in evaluation, comment, and proposal in the research process. Descriptive statistics and comparative methods are the main methods used in the research process.

\section{Research results and discussions}

\subsection{Overview of the development of unburnt building materials in the whole country and the Mekong Delta}

\subsubsection{Developing unburnt building materials nationwide}

Over the past decade, the total design capacity of UBMs production facilities reached 12.62billion standard bricks in 2018, reaching 10.2 billion standard bricks ${ }^{1}$ in 2020. Production and consumption output of UBMs is much lower than design capacity. Total production of UBMs reached only 4.92 billion units in 2018, accounting for about $39 \%$ of design capacity, which increased to about 06billion units in 2019, accounting for about $40-50 \%$ of design capacity. This production of UBMs only accounts for about 30\% of Vietnam's total demand for building materials (20.2billion units/year). According to survey data of the Institute of Building Materials (2019), the production and consumption of UBMs of the whole country are shown in Figure 1.

\footnotetext{
${ }^{1} \mathrm{~A}$ standard brick (unit) is designed to be $220 \mathrm{~mm} \times 105 \mathrm{~mm} \times 60 \mathrm{~mm}$
} 


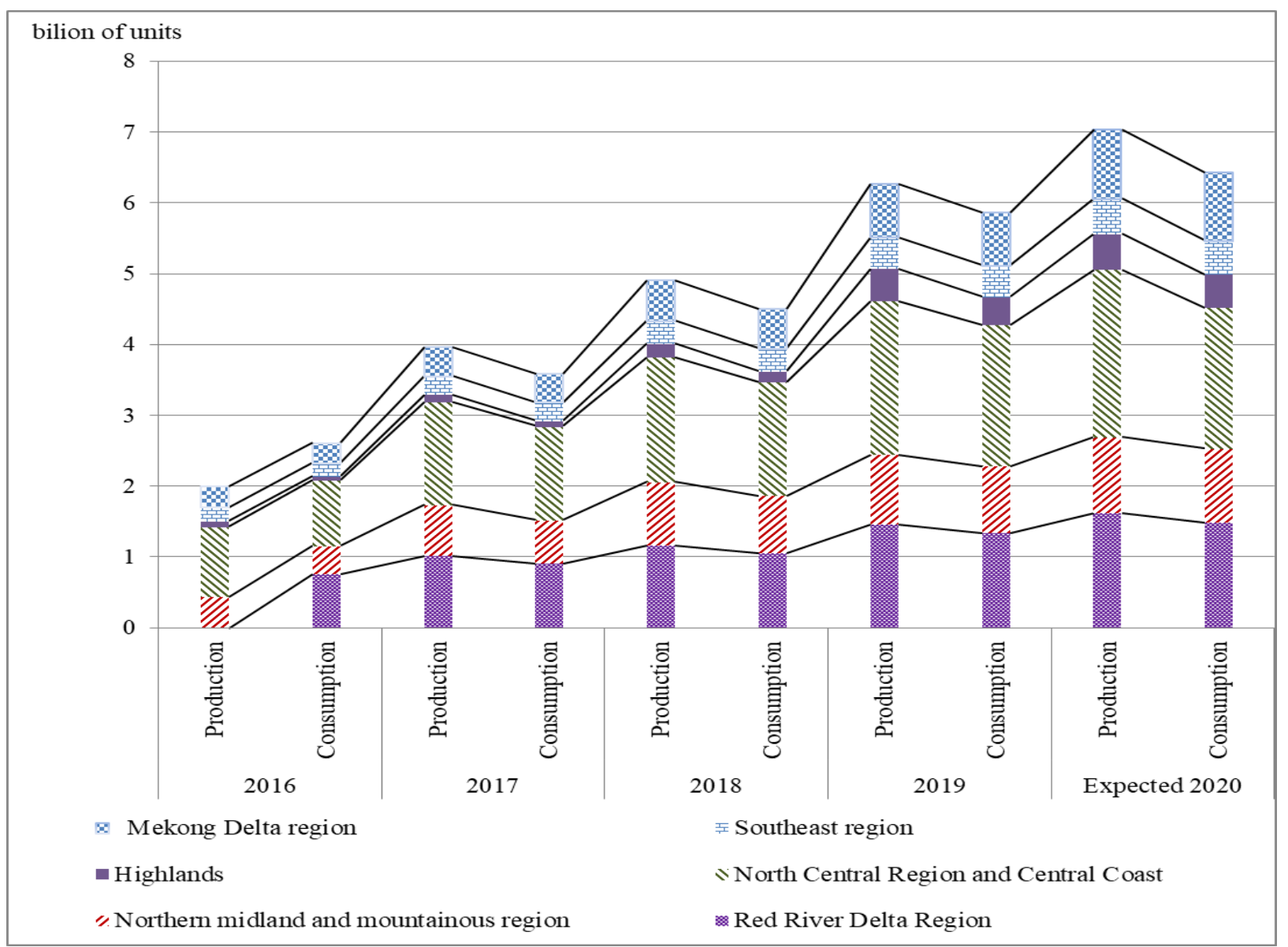

Figure 1. Production and consumption of building materials by regions in Vietnam

Source: Institute of Building Materials (2019)

Figure 1 shows that the production and consumption of UBMs tended to increase gradually over 05 years, from 2016 to 2020. In this period, the average growth rate of UBMs production in the whole country was $35 \%$, and the growth rate of UBMs consumption was $33 \%$ (Ministry of Construction, 2020). Although the average production output reached $40-50 \%$ of the total designed capacity of the UBMs production line, the consumption rate accounted for over $90 \%$ of the total production. Consumption of UBMs has been mainly in state works; public projects are required to use them (Ministry of Construction, 2020). The fact also shows that the UBM industry has also begun to show signs of self-allocating suitable areas for the production and consumption of UBMs. The North Central and Central Coast, the Red River Delta, and the Northern Midlands and Mountains have available and abundant natural materials, which are favorable for the development of UBMs production. These are also economic regions that invest in many UBMs manufacturing facilities with the largest total designed capacity, the largest actual production and consumption in the country (accounting for $77 \%$ of the UBM production and consumption) (Institute of Building Materials, 2019). Next, the Mekong Delta is also an area that can be considered for the development of UBMs production. Areas with few enterprises investing in the production of UBMs include the Central Highlands and the Southeast because the demand for UBMs is not high (the Central Highlands), and there is no suitable source of raw materials for the production of UBMs (Institute of Building Materials, 2019). 


\subsubsection{Development of unburnt building materials in the Mekong Delta}

\subsubsection{Overview of UBMs production in the Mekong Delta}

After a 10-year development period, initiated by a few provinces and cities, now 13/13 provinces and cities in the Mekong Delta have implemented a project to develop the UBM industry in the Mekong Delta and a roadmap to abolish manual clay brick kilns. Accordingly, the number of manufacturers registered to produce UBMs increased from a few to 123 factories. Although there are inefficient manufacturers shutting down, the number of factories registering new operations in 2021 is higher. The production of UBMs in 13 provinces in the Mekong Delta can be divided into 02 groups (Table 1) as follows:

\section{Table 1}

Information on production of unburnt building materials in the Mekong Delta

\begin{tabular}{|c|c|c|c|c|c|c|c|}
\hline No. & $\begin{array}{c}\text { Provinces/ } \\
\text { cities }\end{array}$ & $\begin{array}{c}\text { Number } \\
\text { of } \\
\text { Producer }\end{array}$ & $\begin{array}{c}\text { Number of } \\
\text { manufactur-ers } \\
\text { shutting down }\end{array}$ & $\begin{array}{c}\text { Number of } \\
\text { manufactur-ers } \\
\text { starting in } 2021\end{array}$ & $\begin{array}{c}\text { Total design } \\
\text { capacity } \\
\text { (million } \\
\text { units/year) }\end{array}$ & $\begin{array}{c}\text { Actual } \\
\text { total } \\
\text { capacity } \\
\text { (million } \\
\text { units/year) }\end{array}$ & $\begin{array}{c}\text { Capacity } \\
\text { Usage (\%) }\end{array}$ \\
\hline 1 & An Giang & 20 & 0 & 5 & 250.0 & 67.5 & 27.0 \\
\hline 2 & Hau Giang & 15 & 5 & 1 & 84.2 & 75.8 & 90.0 \\
\hline 3 & Vinh Long & 13 & 4 & 1 & 236.0 & 203 & 86.0 \\
\hline 4 & Can Tho & 10 & 0 & 0 & 27.0 & 22.5 & 83.3 \\
\hline 5 & Kien Giang & 14 & 3 & 3 & 132.5 & 103.5 & 78.1 \\
\hline 6 & Long An & 10 & 0 & 0 & 570.0 & 444.6 & 78.0 \\
\hline 7 & Tra Vinh & 13 & 0 & 4 & 125.2 & 112.0 & 89.5 \\
\hline 8 & Dong Thap & 9 & 0 & 2 & 219.4 & 70.6 & 32.2 \\
\hline 9 & Ben tre & 5 & 0 & 0 & 49.0 & 4.8 & 9.8 \\
\hline 10 & Soc Trang & 5 & 1 & 1 & 36.0 & 28.8 & 80.0 \\
\hline 11 & Ca Mau & 3 & 2 & 0 & 43.0 & 34.4 & 80.0 \\
\hline 12 & Tien Giang & 4 & 0 & 1 & 30.0 & 24.0 & 80.0 \\
\hline 13 & Bac Lieu & 2 & 0 & 0 & 8.0 & 6.4 & 80.0 \\
\hline & Total & 123 & 15 & 18 & $1,810.3$ & $1,197.9$ & 68.76 \\
\hline
\end{tabular}

Source: Collected information from 13 Departments of Construction in the Mekong Delta (2020)

- The group of provinces with a large number of enterprises investing in the production of UBMs and an average annual maximum production capacity of over 10million units include An Giang, Hau Giang, Vinh Long, Kien Giang, and Long An, Tra Vinh, Dong Thap (Except Can Tho, where there are 10 investment enterprises, but the average design capacity of a factory is less than 10million units/year). These are the provinces that have some basic advantages such as having a number of locally available raw materials for production, convenience in product distribution and consumption, rapid urbanization rate. 
- The second group is the group of provinces such as Ben Tre, Soc Trang, Ca Mau, Tien Giang, Bac Lieu that have small capacity UBMs manufacturers (under 10million QTC units/year/factory), mainly to meet a part of the consumption demand in the province due to the lack of raw materials for the production of UBMs available in the province.

- In special cases, in Can Tho alone, the number of manufacturers investing in the province is quite high compared to the regional average, but the investment level of UBMs manufacturers is weak (less than 10million QTC tablets/year). Ben Tre province has a large capacity factory but has not yet operated efficiently (9.8\% capacity utilization).

In addition, according to survey data of 78 manufacturers, most UBMs in the Mekong Delta participating in the survey have a small production capacity. Specifically, the proportion of manufacturers with a design capacity of fewer than 10million units/year, a capacity of over 20million units /year, and between 10 and 20million units /year are 68.0\%, 18.0\%, and 14.1\%, respectively.

Moreover, there are 05 types of UBMs mainly produced in the Mekong Delta. The highest percentage of block bricks is $35.42 \%$, followed by pipe and card bricks (accounting for 34.38\%), self-inserting concrete bricks such as terrazzo, lawn bricks, ventilation bricks (accounting for $28.13 \%$ ), and a small percentage of manufacturers of drywall and concrete panels (2.08\%). There are $67.9 \%$ of manufacturers that have registered and announced standard and technical conformity according to prescribed standards.

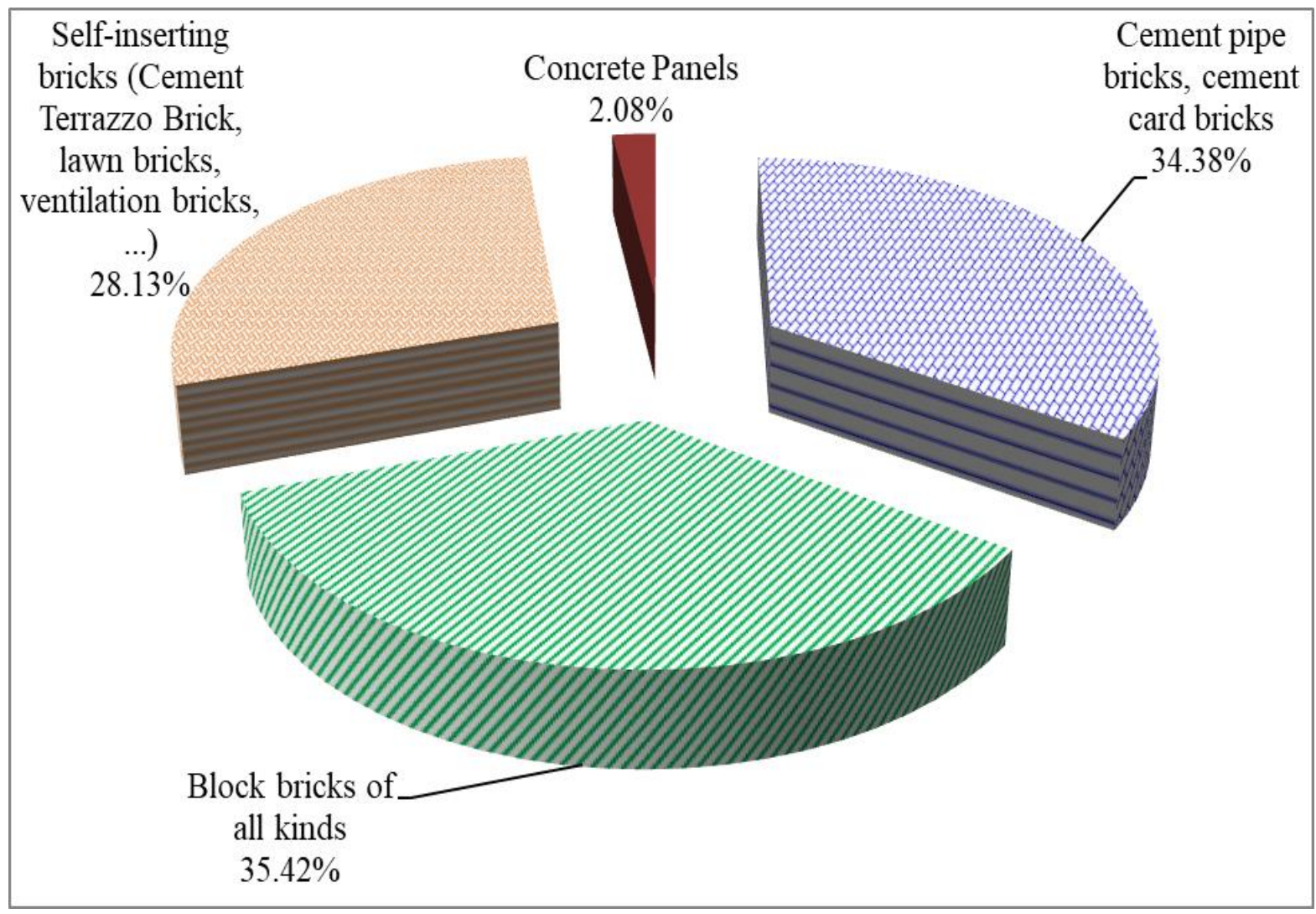

Figure 2. Type of Unburned building materials

Source: Survey results of 78 manufacturers in the Mekong Delta (2020)

Furthermore, manufacturers also self-assess their good relationship with stakeholders in the production and consumption of UBMs. Firstly, they have to build a network of institutional clients, including construction contractors (97.4\%). Second, they are interested in construction 
design consultants who have a lot of knowledge and appreciate the development of UBMs (accounting for 53.8\%). Third, they must create good and active trust with departments and local authorities (50\%). In addition, some manufacturers are very interested in research institutes (26.9\%) in product development. A small number of manufacturers also have a good relationship with investors $(2.6 \%)$.

\section{Table 2}

Production characteristics of UBMs manufacturers

\begin{tabular}{|c|c|c|c|}
\hline Content & $\begin{array}{c}\text { Performance characteristics of the } \\
\text { manufacturer of UBMs }\end{array}$ & $\begin{array}{l}\text { Amount } \\
(n=78)\end{array}$ & $\begin{array}{l}\text { Percent } \\
(\%)\end{array}$ \\
\hline \multirow{4}{*}{$\begin{array}{l}\text { Design capacity (Million } \\
\text { units/year) }\end{array}$} & Less than 05million QTC units/year & 36 & 46.2 \\
\hline & Over 05 to 10 million QTC units/year & 17 & 21.8 \\
\hline & Over 10 - 20million QTC units/year & 11 & 14.1 \\
\hline & Over 20million units or more & 14 & 17.9 \\
\hline \multirow{4}{*}{$\begin{array}{l}\text { Actual production capacity } \\
\text { in } 2019 \text { (million units/year) }\end{array}$} & Less than 05million units/year & 41 & 52.6 \\
\hline & Over 05 to 10 million units/year & 17 & 21.8 \\
\hline & Over 10 - 20million units/year & 8 & 10.3 \\
\hline & Over 20 million units or more & 11 & 14.1 \\
\hline \multirow{2}{*}{$\begin{array}{l}\text { Number of manufacturers } \\
\text { registered and announced } \\
\text { standard and regulation } \\
\text { conformity }\end{array}$} & Yes & 53 & 67.9 \\
\hline & No & 25 & 32.1 \\
\hline
\end{tabular}

Source: Survey results of 78 manufacturers in the Mekong Delta (2020)

\subsubsection{Overview of UBMs consumption in the Mekong Delta}

According to Table 2, the consumption power of UBMs manufacturers in the Mekong Delta can be divided into 03 cases. In the first case, production and use are mainly within the province, including Tien Giang, Dong Thap, Ben Tre, Bac Lieu, Soc Trang, and Ca Mau. This case is due to the small number of producers in these provinces along with small production capacity (under 10million tablets/year/manufacturer), manual technology, not enough to supply the minimum needs of their province. Therefore, to meet the needs of the works, users have to buy UBMs from other neighboring provinces in the Mekong Delta. The second case is that producers with a consumption rate in the province of less than $70 \%$ and the rest outside the province have enterprises in An Giang, Hau Giang, Vinh Long, Can Tho, Kien Giang, Long An, and Tra Vinh. This is because the number of manufacturers in these provinces has an average production capacity of over 10million units/ year/ manufacturer to 100million units/year/ manufacturer, semiautomatic to automatic technology, and can supply to demand on order and linked customers. 
Table 3

Information on consumption of unburnt building materials in the Mekong Delta

\begin{tabular}{clccc}
\hline TT & Provinces/Cities & $\begin{array}{c}\text { Consumption } \\
\text { rate }(\%)\end{array}$ & $\begin{array}{c}\text { Intra-provincial } \\
\text { consumption } \\
\text { Rate }(\%)\end{array}$ & $\begin{array}{c}\text { Consumption rate of } \\
\text { UBMs outside the } \\
\text { province (\%) }\end{array}$ \\
\hline 1 & An Giang & 98.9 & 50.0 & 48.9 \\
2 & Hau Giang & 87.3 & 50.0 & 37.3 \\
3 & Vinh Long & 98.3 & 70.0 & 28.3 \\
4 & Can Tho & 92.6 & 60.0 & 32.6 \\
5 & Kien Giang & 94.0 & 10.0 & 84.0 \\
6 & Long An & 98.6 & 60.0 & 38.6 \\
7 & Tra Vinh & 91.6 & 60.0 & 31.6 \\
8 & Dong Thap & 97.7 & 100.0 & - \\
9 & Ben tre & 97.7 & 100.0 & - \\
10 & Soc Trang & 80.1 & 100.0 & - \\
11 & Ca Mau & 52.8 & 100.0 & - \\
12 & Tien Giang & 89.3 & 100.0 & - \\
13 & Bac Lieu & 86.0 & 100.0 & \\
\hline
\end{tabular}

Source: Survey results of 78 manufacturers in the Mekong Delta (2020)

The survey results of 78 producers in 13 provinces and cities in the Mekong Delta as Table 3 also show that the selling price of UBMs tends to increase compared to the previous year, such as by $5 \%(73.1 \%)$, then by $10 \%$, increased by about $15 \%$, accounting for a very small percentage (only 1.3\%) and the price remained unchanged (accounting for 3.8\%). The reason for the price change is the increase in raw material costs and transportation costs compared to previous years. Furthermore, surveyed manufacturers said that UBMs are produced mainly for consumption in the Mekong Delta region. Indeed, UBMs consumed near the plant site accounts for about $55.1 \%$. The percentage of UBMs that are both consumed in the province and consumed in other provinces in the Mekong Delta is $38.5 \%$. In addition, about $15.4 \%$ serve both Ho Chi Minh City and the Eastern provinces.

It should be stated more clearly that buyers include both organizational and household customers (individuals). According to a survey of these manufacturers, institutional customers account for more than $99 \%$; individual customers account for about $1 \%$ of the total consumption of manufacturers. Direct organizational customers are mainly construction contractors construction materials trading companies.

The survey results of 158 industrial customers of UBMS show that the consumption patterns of UBMs of customers are quite diverse. According to the survey, organizational customers consume UBMs in many different aspects such as civil works (87.3\%), commercial and industrial construction ranked second (79.7\%), trading in building materials (43.7\%), distributing and transporting materials $(23.4 \%)$ and manufacturing brick pressing factories (3.2\%) (see Figure 3). 


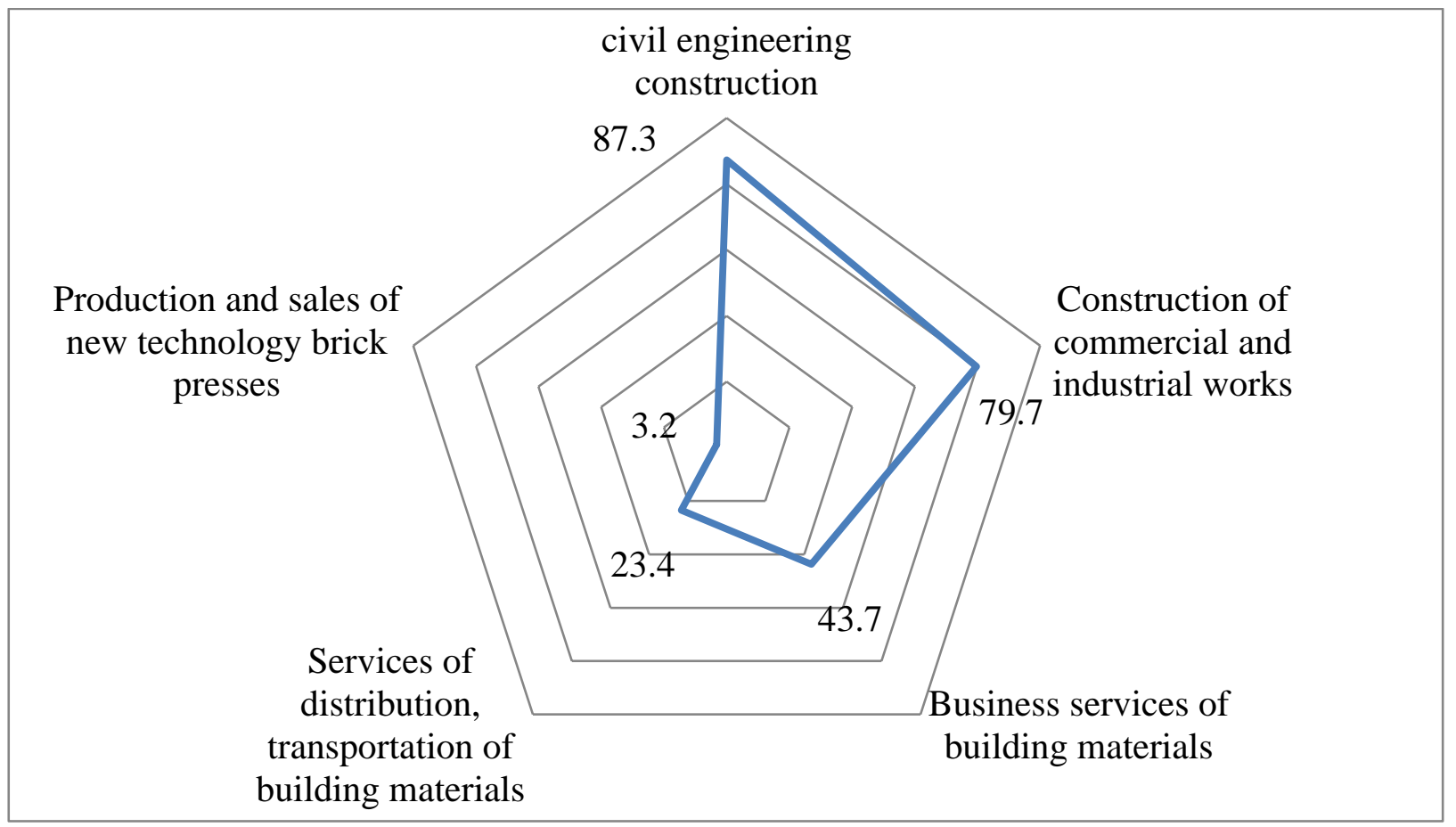

Figure 3. Consumption activities of organizational customers

Source: Survey results of 158 organizational customers (2020)

Also, according to the survey results, as shown in Table 4, the majority of surveyed organizational customers believe that the UBMs consumption market based on revenue in 2019 is increased (88.6\%), unchanged (10.1\%), and decreased (1.3\%). More specifically, in 2019, the percentage of organizational customers who have implemented projects using UBMs ranges from 01 to 03 projects $(40.5 \%)$; from 04 to 06 projects $(37.3 \%)$, from 07 to 10 projects $(16.5 \%)$, and from more than 11 projects (5.7\%). Notably, UBMs are used in $47.5 \%$ of non-state constructions using UBMs, and $5.1 \%$ of construction is for private use only. This proves that the awareness of using UBMs of both construction contractors and customers has changed their usage habits, gradually trusting in UBMs.

\section{Table 4}

How UBMs are used

\begin{tabular}{llcc}
\hline \multicolumn{1}{c}{ Contents } & \multicolumn{1}{c}{ Detail } & $\begin{array}{c}\text { Amount } \\
(\mathbf{n = 1 5 8})\end{array}$ & $\begin{array}{c}\text { Percent } \\
(\%)\end{array}$ \\
\hline $\begin{array}{l}\text { UBMs market by industrial } \\
\text { customers in 2019 (based on } \\
\text { revenue) }\end{array}$ & Increase & 140 & 88.6 \\
& Unchanged & 16 & 10.1 \\
& Reduction & 2 & 1.3 \\
\hline \multirow{2}{*}{$\begin{array}{l}\text { Number of works using UBMs in } \\
2019\end{array}$} & From 01 to 03 projects & 64 & 40.5 \\
& From 04 to 06 projects & 59 & 37.3 \\
& From 11 to 10 projects 15 projects & 26 & 16.5 \\
& Over 16 projects & 6 & 3.8 \\
\hline
\end{tabular}




\begin{tabular}{|c|c|c|c|}
\hline Contents & Detail & $\begin{array}{l}\text { Amount } \\
(n=158)\end{array}$ & $\begin{array}{c}\text { Percent } \\
(\%)\end{array}$ \\
\hline \multirow{3}{*}{ Type of building using UBMs } & $\begin{array}{l}\text { Percentage of customers using } \\
\text { UBMs in state projects } 100 \%\end{array}$ & 83 & 52.5 \\
\hline & $\begin{array}{l}\text { Percentage of customers using } \\
\text { UBMs in public and non-state } \\
\text { projects }\end{array}$ & 67 & 42.4 \\
\hline & $\begin{array}{l}\text { Percentage of customers using } \\
\text { UBMs in private construction } \\
100 \%\end{array}$ & 8 & 5.1 \\
\hline
\end{tabular}

Source: Survey results of 158 organizational customers (2020)

\subsection{Current status of the UBMs consumption channel in the Mekong Delta}

The results of the investigation show that the UBMs of Mekong Delta have 02 main consumption channels (Figure 4).

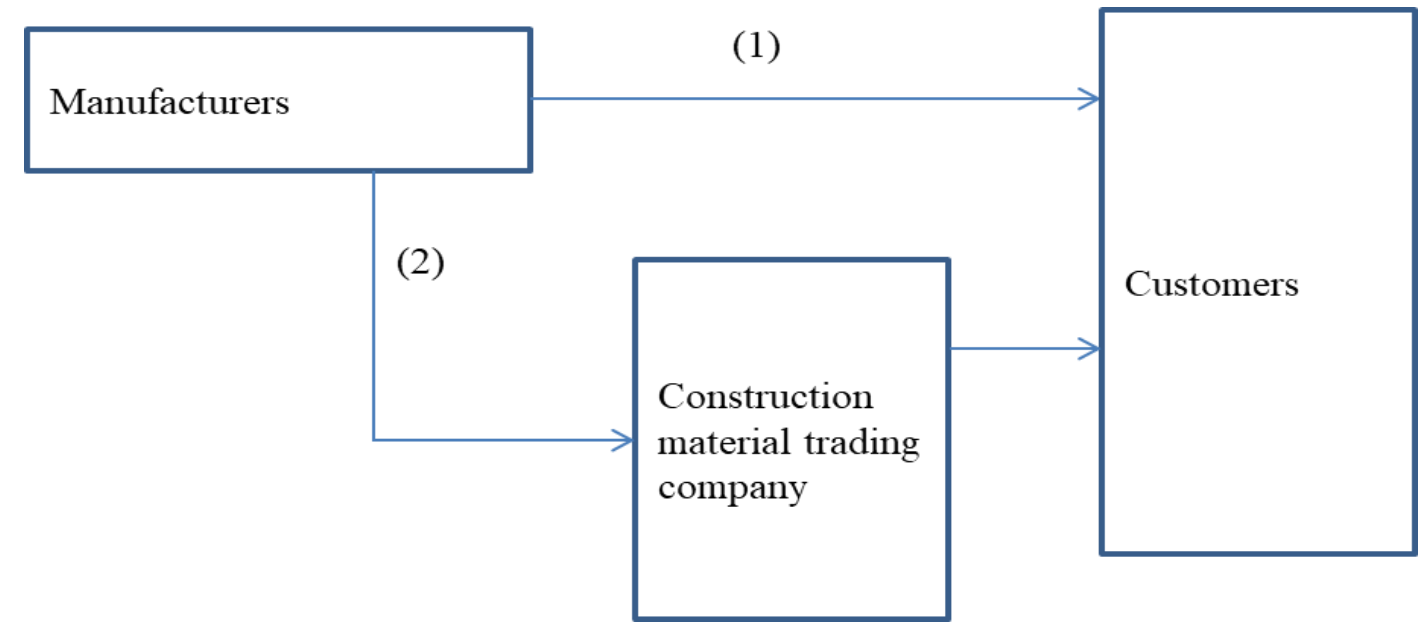

Figure 4. Consumption channel of UBMs in Mekong Delta

Source: Author's compilation

Channel 1 is a direct sales channel for UBMs, and mainly, manufacturers directly sell products to construction companies. This channel consumes most of the different types of UBMs. According to this channel, the manufacturer sells the highest price (equal to the retail price) with shipping costs due to the fact that the company buys it with cash or deferred payment. Mostly, buyers prefer the deferred payment method, and sellers accept deferred payment within 01 month (74.4\%), late payment in 02 - 03 months (41.0\%), late payment in 03 - 06 months $(47.4 \%)$. There are two main delivery methods, in which the must-have delivery method is the manufacturer delivering the UBMs to the construction site to the customer (accounting for 100\%) within a radius of 30 to $50 \mathrm{~km}$ or the customer self-carrying / outsourcing (about 56.4\%). The selling price is agreed upon through a contract between the seller and the buyer. If the buyer pays in cash, the price to pay for construction materials is lower, ranging from $5 \%$ to $10 \%$ compared to the deferred payment method.

Channel 2 is an indirect channel for consuming UBMs with one level, only appearing about 03 years ago. In this channel, construction material companies sell part of their products to UBMs to supply to retail customers. Most of the UBMs consumed through this channel are mainly block 
bricks, terrazzo cement bricks, aerated bricks, etc. Consumption through this channel accounts for about $10 \%$ of total products produced. Manufacturers incur a fee to cover transaction and shipping costs, but in return they sell in stable quantities and are paid on time according to the contract.

\subsection{Factors affecting the consumption of UBMS in the Mekong Delta}

\subsubsection{Reasons for customers to choose UBMs manufacturers}

In the consumption of UBMs, customers say that some of the reasons customers are interested in choosing products include the reasonable product price $(94.3 \%)$, fast delivery speed $(63.9 \%)$, product quality as committed $(57 \%)$, good technical support and after-sales service (35.4\%), enthusiastic and clear product introduction (37.3\%), and product variety (35.4\%) (see Figure 5).

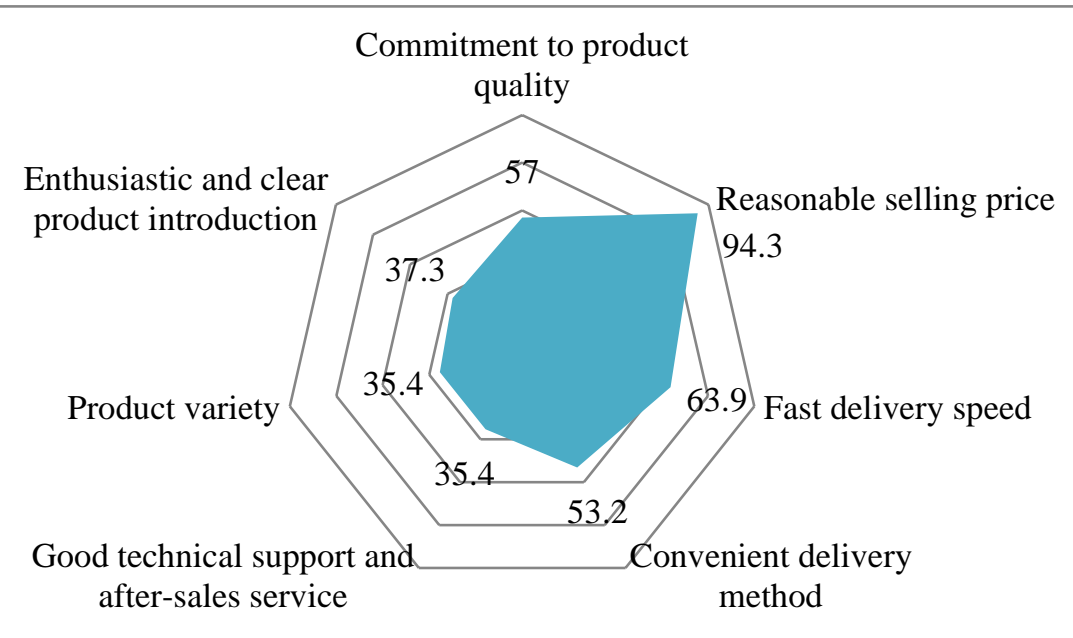

Figure 5. Reasons for customers to choose Manufacturer's products

Source: Survey results of 158 organizational customers (2020)

\subsubsection{Product consumption link}

In business, the link between production and product consumption has always been identified as a key stage for efficient production. However, the link in the current consumption of UBMs in the Mekong Delta has not really developed strongly. According to the results of in-depth interviews, manufacturers of UBMs now rely on the interest of departments and local authorities to introduce and promote their products through registration of standard and technical conformity (45\%) (See Figure 6). In addition, relying on the industrial customer network, which is a network of contractors (43\%) expands the consumption relationship of UBMs by the product quality and manufacturer's reputation. Some manufacturers who are interested in the research and development of new products but do not have the capacity in terms of experimental infrastructure and research level should look to universities and research institutes for implementation (15.2\%). Thereby improving the reputation of the manufacturer when the product meets the actual needs of customers. Moreover, manufacturing enterprises have not joined or promoted links with material associations and construction associations to support the development of product consumption markets jointly. 


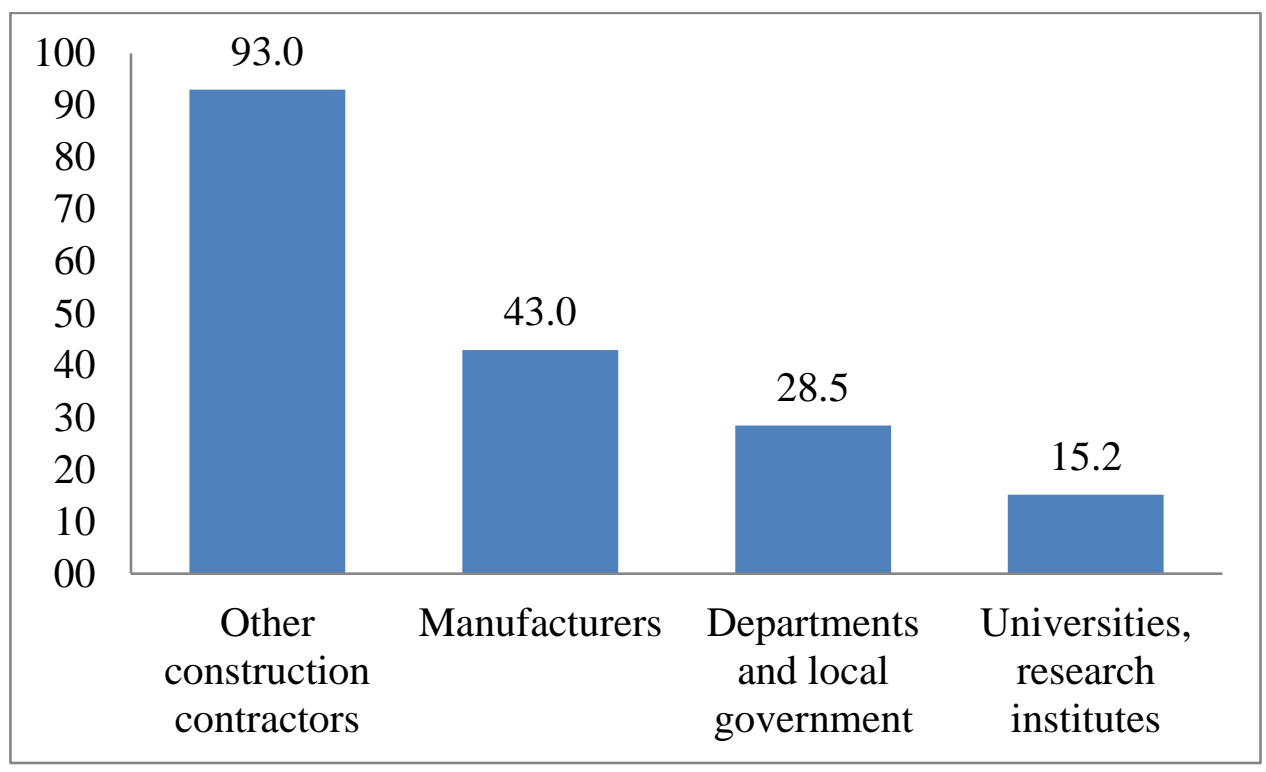

Figure 6. Product consumption link of manufacturers

Source: Survey results of 78 manufacturers (2020)

\subsubsection{Capacity of manufacturers}

+ About production technology and product quality management: To ensure that UBMs meet customer needs in terms of quality, safety, and optimize production costs, manufacturers must have a good understanding of the technology; fully apply the conditions and standards of the production process to the production of UBMs. Currently, UBMs in Mekong Delta are mainly cement block bricks, cement pipe, card bricks, and self-inserting concrete bricks, produced on lines with a small and medium capacity, manual and semi-automatic technology and unsynchronized chain. In addition, the survey results also show that about $32.1 \%$ of products of manufacturers have not met the requirements for registration of standard conformity and compliance with product quality announcements. There is still a situation where the concrete bricks are not old enough to be shipped from the warehouse and put into the works, causing strong shrinkage in the masonry causing cracking.

+ Skill level of workers: Technical staff and workers have not been properly trained and have not well-controlled factors affecting product quality.

+ About product designs: Many manufacturers use the standard size of baked clay bricks to produce unburnt bricks ( $34.38 \%$ of Cement pipe bricks and cement card bricks), so the strengths of UBMs have not been brought into play. For example, producing UBMs with large size and large porosity reduces material consumption and lowers costs. In addition, the number of manufacturers of large plate UBMs is small $(2.08 \%)$, so this type of structure is not yet popular despite having many advantages in quality, fast construction speed, saving on auxiliary materials, being suitable for soft soil in the Mekong Delta, good sound and heat insulation and reduced cost when applied in large volumes in high-rise buildings.

+ About product selling price: Currently, the selling price of UBMs is still not attractive and can't compete with baked clay bricks. Firstly, the manufacturer has not really optimized the production process to reduce the cost of UBMs. Second, the resources used to produce UBMs and baked clay bricks have not been properly evaluated, so they have not created a motivation for saving material resources. 
+ Sales and after-sales policies of manufacturers: Not many enterprises producing UBMs have built up qualified technical and human business resources. One of the most obvious limitations of this team is that they have not been proactive and active in following up with the works, providing technical guidance on the construction of materials and accessories, timely technical handling for cracking incidents, water absorption, etc.

\subsubsection{Capacity of constructors using UBMs}

+ Compliance with technical processes: Some construction contractors, when using UBMs, still do not comply with construction instructions on the moisture content of bricks, corresponding types of materials, and accessories (fiberglass mesh, wall anchors, etc.). As a result, it causes cracking and separation from columns when the works are put into use in some provinces (such as Ben Tre), which reduces users' trust in UBMs;

+ Skill level of construction workers: Skilled workers in the construction of UBMs in the Mekong Delta are getting better and better guidance, but they still cannot meet the increasing requirements in construction. Because UBMs are not yet popular materials, construction requires the synchronization of materials and equipment. Currently, most construction workers are only familiar with the construction of baked clay bricks not proficient in the construction of UBMs of larger sizes, which has affected the progress and quality of the work, leading to a reduction in the ability to apply UBMs in practice.

\subsubsection{Consumer attitudes and beliefs}

Consumers' attitudes and beliefs: Consumers have not seen all the benefits of UBMs, such as soundproofing, thermal insulation, saving electrical energy during use, and reducing building operating costs. In addition, they have not yet clearly realized that the use of UBMs is responsible for saving clay resources, saving fuel, and protecting the environment to ensure sustainable development. Some reasons are due to D. T. Nguyen (2013) evaluated as (1) because sustainable consumption in Vietnam has hardly been paid attention, ecological products have not had a place in the market, sustainable consumption habits have not been oriented in the whole society; (2) UBMs are still limited in quality and competitive in price.

\subsection{Some key solutions to promote sustainable consumption of UBMs in the Mekong} Delta

\subsubsection{Solutions for planning and organizing production}

\subsubsection{Planning and implementation of the plan}

It is necessary to have a unified and detailed development plan of UBMs for the Mekong Delta. Provinces with advantages near raw materials such as Long An, An Giang, Kien Giang, and Tra Vinh are the provinces that should prioritize the implementation of the development plan of Block bricks of all kinds; Cement pipe bricks, cement card bricks, and Self-inserting bricks). Other provinces consider concrete Panels development planning based on the assessment of strengths and needs in each locality. Publicize and propagate widely, regularly implement planning contents. Increase investment in infrastructure construction for production areas and transport infrastructure.

\subsubsection{Organization of production}

+ Regarding implementation in localities: Departments and local authorities should not only pay more attention to calling for enterprises to invest in the production of UBMs, promote the increased use of UBMs, but also call for specifically restricting the production and use of fired clay bricks. To be effective at the district level, provincial departments need to issue specific 
guiding policies to implement the detailed UBMs development program. The propaganda about the benefits of using UBMs in each locality (province, city in the Mekong Delta) needs to be invested in time and depth so that users can fully understand the use of UBMs. For manufacturers, priority should be given to calling for medium-sized investors with an average or higher production capacity and semi-automatic production technology. Local policymakers need to call on existing manufacturers with manual UBMs production technology to gradually switch to semi-automatic and more synchronous production technology in the production line.

+ Regarding investment incentive policies: In fact, in some localities in the Mekong Delta, many enterprises investing in new or expanding production of UBMs have not yet enjoyed incentives as prescribed in Decision 567 of the Prime Minister (Prime Minister, 2010) as well as Decree No. 108/2006/ND-CP dated September 22, 2006 of the Government (Government, 2006). In addition, there is no guidance on the use of the Technology Transfer Fund as stipulated in Decision 567 (Prime Minister, 2010), so enterprises have not been fully and universally entitled to incentives. Therefore, policymakers in the Mekong Delta need to pay attention to using these two policies.

+ System of standards, regulations, economic and technical norms: The promulgation of construction instructions for each type of UBM, norms for using different types of UBMs, pricing and announcement of prices for each type UBMs need to be realistic to promote the use of UBMs.

\subsubsection{Solutions for market organization and trade promotion}

Develop and promote the benefits of using UBMs: On the basis of product development practices (product innovation and product quality), develop and implement programs and projects to build UBMs brand for each locality in the Mekong Delta to meet needs and create trust with consumers. Branding must be associated with the interests of the manufacturer. Organize exhibitions promote UBMs to consumers inside and outside the Mekong Delta. In addition, annually conduct surveys and select products with manufacturers and contractors that have innovated UBMs to honor. This tool creates buzz connecting manufacturers with partners in the UBMs consumption system inside and outside the Mekong Delta.

Building horizontal and vertical linkages between manufacturers and intermediaries in the consumption of UBMs: With two current distribution channels, the distribution system of UBMs is simple, with few intermediaries, so costs for customers have been minimized. With the rate of UBM consumption in the second consumption channel through construction material trading companies is $10 \%$ of the total consumption, appearing in the last 03 years shows that the Government's development programs and local authorities on UBMs have had an effect. These programs are carried out by diffusing the use of UBMs in large-scale and high-value public works to construction works in people's lives. However, the quality factor of UBMs associated with the demand for use in the Mekong Delta needs to be further improved so that UBMs can really replace fired clay bricks in a convincing way. Therefore, channel 2 needs to be further promoted in association with quality product certification with integrated labels and packages according to the manufacturer's brand to help buyers distinguish qualified products and increase trust.

\section{Conclusion}

Developing UBMs is identified as one of the important goals to develop new materials in construction. The development of UBMs is considered as one of the main responses to protect the environment and improve lives through sustainable development of the Mekong Delta. In fact, in our country today, sustainable production and consumption have not been paid attention to, and implementation activities are still limited. In Vietnam, consumption habits are governed by 
customs, practices, and economic ability. With the strong economic development momentum in the past 10 years, many consumption habits are still a matter of concern for research and improvement. One of the origins of UBMs development in the direction of sustainable development originates from the production and use of UBMs in public projects; state works are just individual activities. When the provinces and cities in the Mekong Delta implement the local Government's development program, they are not connected with each other; the scope of impact is only within the framework of a group of direct beneficiaries, so it is not widespread and sustainable for the region. Although the production and consumption of UBMs in the Mekong Delta is still slow and fraught with obstacles, the number of producers and the volume of UBMs used increases each year. The biggest obstacle at present is the limitation of the innovation capacity of manufacturers, the capacity of contractors to construct UBMs, and the low confidence of consumers in UBMs products. Strengthening the link between manufacturers and UBMs consumption partners, promoting product branding, strengthening sales promotion innovation activities, etc., are the main solutions to promote this industry to develop more in the Mekong Delta in the future.

\section{References}

Government. (2006). Decree No. 108/2006/ND-CP of the Government: Detailing and guiding the implementation of a number of articles of the Investment Law. Retrieved June 10, 2021, from https://vanban.chinhphu.vn/default.aspx?pageid=27160\&docid=16135

Institute of Building Materials. (2019). Report some current production issues of UBMS in Vietnam. Hanoi, Vietnam: Ministry of Construction.

Ministry of Construction. (2020). Summary of 10 years of implementation of the program to develop unburnt building materials and the project of handling and using ash, slag, and gypsum. Retrieved June 10, 2021, from https://moc.gov.vn/vn/tin-tuc/1173/64873/hoi-nghi-tong-ket10-nam-thuc-hien-chuong-trinh-phat-trien-vat-lieu-xay-khong-nung-va-de-an-day-manh-xuly--su-dung-tro--xi--thach-cao.aspx

Ministry of Construction. (2012). Circular No. 09/2012/TT-BXD of the Ministry of Construction: Regulations on use of unburnt construction materials in construction works on November 28, 2012. Retrieved June 10, 2021, from https://vanban.chinhphu.vn/default.aspx?pageid=27160\&docid=165522

Ministry of Construction. (2017). Circular No. 13/2017/TT-BXD of the Ministry of Construction: Regulations on use of unburnt construction materials in construction works issued on December 8, 2017. Retrieved June 10, 2021, from https://vanban.chinhphu.vn/default.aspx?pageid=27160\&docid=192748

Ministry of Construction. (2019). Project on development of production and use of unburnt building materials. Hanoi, Vietnam: Construction Publisher.

Nguyen, K. M. (2000). Decision of the Minister of Construction No. 15/2000/QD-BXD dated July 24, 2000 on promulgating regulations on investment in production of baked clay bricks and tiles. Retrieved June 10, 2021, from https://thuvienphapluat.vn/van-ban/Tai-nguyen-Moitruong/Quyet-dinh-15-2000-QD-BXD-Quy-dinh-dau-tu-san-xuat-gach-ngoi-dat-set-nung46570.aspx 
Nguyen, D. T. (2013). Sustainable production and consumption in Vietnam - Current situation and solutions. Retrieved June 10, 2021, from http://tapchimoitruong.vn/phap-luat--chinh-sach16/S\%E1\%BA\%A3n-xu\%E1\%BA\%A5t-v\%C3\%A0-ti\%C3\%AAu-th\%E1\%BB\%A5b\%E1\%BB\%81n-v\%E1\%BB\%AFng-\%E1\%BB\%9F-Vi\%E1\%BB\%87t-Nam--Th\%E1\%BB\%B1c-tr\%E1\%BA\%A1ng-v\%C3\%A0-gi\%E1\%BA\%A3i-ph\%C3\%A1p-19367

Prime Minister. (2010). Decision No. 567/QD-TTg dated April 28, 2010 of the Prime Minister approving the unmarried construction materials development program by 2020. Retrieved June 10, 2021, from http://moc.gov.vn/vn/Pages/ChiTietVanBan.aspx?vID=738\&TypeVB=0

Prime Minister. (2011). Decision approving the National Strategy on Climate Change No. 2139/QDTTg. Retrieved June 10, 2021, from https://vanban.chinhphu.vn/default.aspx?pageid=27160\&docid=152841

Prime Minister. (2020). Decision No. 1266/QD-TTg dated August 18, 2020 of the Prime Minister for approval of Vietnam's construction materials development strategy in the period 2021 2030, oriented to 2050. Retrieved June 10, 2021, from https://tulieuvankien.dangcongsan.vn/he-thong-van-ban/van-ban-quy-pham-phap-luat/quyetdinh-so-1266qd-ttg-ngay-1882020-cua-thu-tuong-chinh-phu-phe-duyet-chien-luoc-phattrien-vat-lieu-xay-dung-viet-nam-thoi-ky-6746 